\title{
Enhancing of nitrogen fixation by legumes
}

\author{
Sarra A. Bekuzarova ${ }^{1, *}$, Aslanbek Kh. Kozyrev², Irina A. Shabanova ${ }^{3}$, Geracim V. \\ Lushenko ${ }^{4}$, and Larisa I. Weissfeld ${ }^{5}$ \\ ${ }^{1}$ Gorsky State Agrarian University, Department of Agriculture, Plant Growing, Crop Breeding and \\ Seed Production, 362040 Vladikavkaz, Russia \\ ${ }^{2}$ Gorsky State Agrarian University, Department of Ecology and Land Management, 362040 \\ Vladikavkaz, Russia \\ ${ }^{3}$ Gorsky State Agrarian University, Department of Production Technology, Storage and Processing of \\ Crop Products, 362040 Vladikavkaz, Russia \\ ${ }^{4}$ Vladikavkaz Scientific Centre of the Russian Academy of Sciences, The North Caucasian Research \\ Institute of Mountain and Piedmont Agriculture, 363110 Mikhailovskoye, Russia \\ ${ }^{5}$ Institute of Biochemical Physics named after N.M. Emanuel of the Russian Academy of Sciences, \\ Department of Biology, 119334 Moscow, Russia
}

\begin{abstract}
To increase the legumes' nitrogen fixation, the seeds were treated with a mixture of biopreparations of 4-aminobenzoic acid (PABA) at a concentration of $0.05 \%$ aqueous solution, to with adding of "Nikfan" biopreparation in an amount of $0.1 \%$ of the solution volume. The seeds of leguminous grasses such as clover and alfalfa were soaked in this mixture, and 10-15 days after emergence of seedlings, foliar feeding of this concentration was carried out. In the phase of budding and the beginning of flowering, plant productivity was accounted and active nodules were counted. We used variants with seed treatment by industrial strains for each culture, as well as without biopreparation treatment, as a control experiment. As a result of the obtained data, it was found that the use of a biopreparations mixture significantly increases the number of nodules, more biological nitrogen is accumulated in the soil, and protein content in the herbage increases. Correlation was established between the number of nodule bacteria and leaf area at the $4^{\text {th }}-5^{\text {th }}$ internodes in clover and the $6^{\text {th }}-7^{\text {th }}$ in alfalfa.
\end{abstract}

\section{Introduction}

Clover and alfalfa are the traditional legumes in the North Caucasus, therefore biological nitrogen is accumulated in the soil, which is necessary for the subsequent crop rotation. To increase their nitrogen-fixing ability, the industrial strain - Rhizobium is used in most cases. However, with this treatment (seed inoculation), a competition between natural, often ineffective races and artificially created strains occurs, in favor of the latter $[1,2,3,4]$. Therefore, it becomes necessary to create varieties with high nitrogen-fixing ability, that is, formation of nodules of bacteria that are capable of fixing nitrogen from the air with formation of the rhizobium-legume symbiosis.

\footnotetext{
*Corresponding author: bekos37@mail.ru
} 
It is known that the rhizobium-legume symbiosis is a consequence of the evolutionary activity of leguminous plants and nodule bacteria, the result of conjugate natural selection in the process of its historical development. The high degree of heritability of symbiotic characters and the direct relationship between nitrogen-fixing ability and plant productivity testify in favor of the effectiveness of symbiotic selection $[5,6,7]$.

For a long period of time microbiologists dealt with issues of nitrogen fixation of legumes without contacting the plant breeder on such an important matter $[8,9,10]$.

A number of agricultural scientists and plant breeders found that the sign of nodule formation in the rhizosphere of leguminous plants fully depends not only on the use of industrial strains, i.e., on inoculation of seeds, but also on optimal options for soil moisture, varietal differences, micronutrient feeding (boron, molybdenum, vanadium and others), temperature, and most importantly - soil acidity [8,11,12].

Given these important parameters for the full development of nitrogen fixation of leguminous plants, agricultural methods that have proved the possibility of increasing the mass of nodules of each plant, their leghemoglobin content, their size and the amount of biological nitrogen accumulated in the soil have been developed $[10,11,13]$.

At the All-Russian Williams Fodder Research Institute and a number of other organizations have gained vast experience in creating new varieties of clover, adaptive to acidic soils and accumulate biological nitrogen in sufficient quantities $[9,11,12]$.

Having knowledge in the field of increasing nitrogen fixation of legumes, scientists have proved that there are a number of biological products that can increase the leghemoglobin in nodules and their amount in accumulation of biological nitrogen on leached chernozems of the North Caucasus region [6].

One of these biological products are the para-aminobenzoic acid and "Nikfan", which were used in a mixture.

However, such mixtures were not used directly on legumes. Besides that, the effects of these mixtures on the number of nitrogen-fixing bacteria were not observed during the period of the onset of development and after mowing down.

The objective of our research is to study the effect of a mixture of two biopreparations on increasing the nitrogen-fixing ability of legumes.

\section{Materials and methods}

The experiments were conducted during 2017-2019 at the experimental site of the North Caucasus Research Institute of Mountain and Piedmont Agriculture. Regional varieties of "Daryal" clover and "Kevsala" alfalfa were used for the experiment. The experimental soils were the leached chernozem, medium loamy, with acidity of $\mathrm{pH}$ 5.9-6.1.

Before sowing, the seeds were kept for 2-3 hours in an aqueous solution of PABA at a concentration of $0.05 \%$, i.e. $5 \mathrm{~g}$ of powder per 1 liter of water. Biopreparation "Nikfan" was introduced into such a solution in $0.1 \%$ of the total volume of the solution. Before preparing the solution, PABA powder was dissolved in hot water at a temperature of $70-80{ }^{\circ} \mathrm{C}$. After cooling the PABA solution to a temperature of $20-25^{\circ} \mathrm{C}, 10 \mathrm{ml}$ of the "Nikfan" product was introduced and the clover and alfalfa seeds were kept in it.

Nodules were taken accounted during the budding phase and the beginning of flowering, since the maximum number of nitrogen-fixing bacteria accumulates during this period. Nitrogen-fixing ability was determined by the accumulation of plant biomass and biological nitrogen in the soil, by counting the number of nodule bacteria and their mass and by staining with pink or red color of 10 plants at least.

The clover and the alfalfa leaf areas were determined at the $4^{\text {th }}-5^{\text {th }}$ and the $6^{\text {th }}-7^{\text {th }}$ internodes, respectively, during the period of complete budding, as well as their protein content, which was determined in the laboratory of the Gorski SAU. The staining intensity 
of nodules indicates a high content of leghemoglobin in bacteria strains of the legume root system. The same solution was additionally used for foliar feeding 10-15 days after seedling emergence, that is, when the development of nodule bacteria begins.

The control experiment was the option without seed treatment and foliar feeding, as well as a commercial industrial bacterial strain - 348 for clover and 425 for alfalfa [2]. The correlation coefficient was determined between the number of active nodules and the rate of regrowth after mowing ( $\mathrm{rl}$ ), and also between the herbage protein content and the number of formed nodules (r2).

\section{Results and discussions}

Biological product "Nikfan" is an extract of phytohormones that are obtained from microorganisms of certain strains. This biofertilizer is intended for seed treatment and plant vegetation. It is highly active during the period of lack of moisture in the soil as a strong antistress drug and root-forming agent.

Simultaneously with an increase of nodule bacteria, the aboveground biomass of cultivated crops also increases, the immunity of plants increases, the ripening time is reduced by $1-2$ weeks, and yield is increased by $30-70 \%$. The used product has a multifaceted effect on the activation of root formation, an increase in the leaf surface, the stem thickness, and the photosynthesis intensity. An increase in the volume of the root system also contributes to an increase in the number of nodules.

The main active components of the preparation are the primary producer's metabolism products: amino acids, enzymes, growth substances, including phytohormones (cytokinins, auxins), as well as components containing humic substances that ensure stability of the preparation's properties. The observed biological effects of the biological product are achieved by improving the nutrition of the vegetative organs, stimulating photosynthesis, and regulating the plant's own genes at the molecular level by the principle of hormonal signals in plants due to the penetration of the active parts of the product using protein receptors through the plant cell membrane.

The biopreparation in such a concentration $(0.1 \%)$ of an aqueous solution achieves high efficiency, while reducing soil toxicity. Especially, its effectiveness is manifested when the prepared solution is dissolved in a $0.05 \%$ PABA aqueous solution. This dose is justified by the stimulating effect as an activator of living organisms, including various strains contained in "Nikfan". At a higher concentration, the solution is acidified, which does not provide the full activity of "Nikfan".

PABA, as a vitamin $\mathrm{H}^{1}$, is widespread in the nature. The growth factor of numerous organisms (including those inhabiting the intestines of animals and humans) that synthesize folic acid from it.

Being an integral part of folic acid, PABA promotes the synthesis of purines and pyrimidines, and, therefore, the RNA and DNA, and affects the metabolism of some biogenic amines.

The results of the experiments showed that the number of active nodules (stained in pink or red) positively correlates with the growth rate after mowing, and the protein content in the leaves with their maximum area. The maximum leaf area was noted at the $4^{\text {th }}-5^{\text {th }}$ internodes in clover and the $6^{\text {th }}-7^{\text {th }}$ in alfalfa, which, in comparison with the control variants, determined the stimulating effect of the mixture of PABA and "Nikfan".

Table 1 presents the results of studies on the effect of a mixture of biopreparations on the legume nitrogen-fixing ability. 
Table 1. Effect of PABA and "Nikfan" biopreparations on nitrogen-fixing ability of clover.

\begin{tabular}{|c|c|c|c|c|c|c|}
\hline $\begin{array}{l}\text { Experiment } \\
\text { options }\end{array}$ & $\begin{array}{l}\text { Number } \\
\text { of } \\
\text { active } \\
\text { nodules } \\
\text { per } \\
\text { plant, } \\
\text { pcs. }\end{array}$ & $\begin{array}{l}\text { Regrowth } \\
\text { after } \\
\text { mowing } \\
\text { the } \\
\text { herbage, } \\
\mathrm{cm}\end{array}$ & $\begin{array}{l}\text { Correlation } \\
\text { coefficient, } \\
\text { r1, between } \\
\text { regrowth } \\
\text { and } \\
\text { number of } \\
\text { nodules }\end{array}$ & $\begin{array}{l}\text { Accumulation } \\
\text { of biological } \\
\text { nitrogen in } \\
\text { the soil, } \mathrm{kg} / \mathrm{ha}\end{array}$ & $\begin{array}{c}\text { Leaf } \\
\text { protein } \\
\text { content, } \\
\%\end{array}$ & $\begin{array}{c}\text { Correlation } \\
\text { coefficient } \\
\text { between } \\
\text { protein } \\
\text { content and } \\
\text { number of } \\
\text { active } \\
\text { nodules, } r 2 \\
\end{array}$ \\
\hline $\begin{array}{l}\text { Control (without } \\
\text { biopreparations) }\end{array}$ & 38 & 1.28 & 0.67 & 95.8 & 18.8 & 0.72 \\
\hline $\begin{array}{l}\text { Inoculation with } \\
\text { the } 348 \text { strain }\end{array}$ & 46 & 1.46 & 0.79 & 138.5 & 19.1 & 0.76 \\
\hline $\begin{array}{l}\text { Pre-sowing } \\
\text { treatment in the } \\
\text { PABA aqueous } \\
\text { solution }\end{array}$ & 54 & 1.76 & 0.82 & 153.6 & 19.6 & 0.78 \\
\hline $\begin{array}{l}\text { Pre-sowing } \\
\text { treatment in the } \\
\text { "Nikfan" } \\
\text { aqueous solution }\end{array}$ & 59 & 1.85 & 0.91 & 174.3 & 20.1 & 0.80 \\
\hline $\begin{array}{l}\text { Pre-sowing } \\
\text { treatment by } \\
\text { PABA + } \\
\text { "Nikfan" }\end{array}$ & 72 & 1.92 & 0.92 & 186.8 & 20.8 & 0.88 \\
\hline $\begin{array}{l}\text { Pre-sowing } \\
\text { treatment with a } \\
\text { biopreparations } \\
\text { mixture + foliar } \\
\text { fertilizing } 10-15 \\
\text { days after } \\
\text { germination }\end{array}$ & 92 & 2.10 & 0.94 & 218.6 & 21.2 & 0.90 \\
\hline
\end{tabular}

The experimental results indicate that the correlation coefficient between the number of nodule bacteria and the protein content in the herbage is quite high, since the amount of biological nitrogen directly affects the quality indicators. In addition, its content in the soil also increases, which is very important for subsequent crops in the crop rotation, going along the layer of legumes. The results on germination of seeds treated with such a composition were also noted.

It was determined that in the optimal case, when using a mixture of two biopreparations, germination occurred 2-3 days earlier than in the control cases (without fertilizers and inoculation with an industrial strain.). Similar data were obtained during the processing of alfalfa seeds, from which it follows that the increase in the nitrogen fixation is quite closely correlated with the regrowth rate of plants after mowing, and an increase in the protein content of plant leaves, the number of active nodules increases significantly. Table 2 presents data on the indicators of nitrogen-fixing ability of alfalfa depending on phenotypic features.

According to Table 2, we can determine the positive properties of a mixture of 2 biological products during seed treatment and additional foliar feeding, after which the number of active nodules increases from $64 \mathrm{pcs}$. in the control experiment to $158 \mathrm{pcs}$. in the optimal case, the protein content growths from $19 \%$ to $20.8 \%$, and most importantly, the content of biological nitrogen in the soil, which is replenished due to the proposed agricultural methods, increases. 
Table 2. Effect of a biopreparations mixture on the nitrogen-fixing ability of alfalfa.

\begin{tabular}{|l|c|c|c|c|c|c|}
\hline \multicolumn{1}{|c|}{$\begin{array}{c}\text { Experiment } \\
\text { options }\end{array}$} & $\begin{array}{c}\text { Number } \\
\text { of } \\
\text { active } \\
\text { nodules } \\
\text { per } \\
\text { plant, } \\
\text { pcs. }\end{array}$ & $\begin{array}{c}\text { Regrowth } \\
\text { after 2-3 } \\
\text { days after } \\
\text { mowing, } \\
\text { in cm }\end{array}$ & $\begin{array}{c}\text { Correlation } \\
\text { coefficient, } \\
\text { r1, } \\
\text { between } \\
\text { regrowth } \\
\text { and } \\
\text { number of } \\
\text { nodules }\end{array}$ & $\begin{array}{c}\text { Accumulation } \\
\text { of biological } \\
\text { nitrogen in } \\
\text { the soil, kg/ha }\end{array}$ & $\begin{array}{c}\text { Leaf } \\
\text { protein } \\
\text { content, } \\
\%\end{array}$ & $\begin{array}{c}\text { Correlation } \\
\text { coefficient } \\
\text { between } \\
\text { protein } \\
\text { content } \\
\text { and } \\
\text { number of } \\
\text { active } \\
\text { nodules, r2 }\end{array}$ \\
\hline $\begin{array}{l}\text { Control (without } \\
\text { seed treatment } \\
\text { and feeding) }\end{array}$ & 64 & 1.32 & 0.68 & 124.0 & 19.0 & 0.74 \\
\hline $\begin{array}{l}\text { Inoculation with } \\
\text { the 425 strain }\end{array}$ & 74 & 1.46 & 0.74 & 146 & 19.4 & 0.76 \\
\hline $\begin{array}{l}\text { Pre-sowing seed } \\
\text { treatment in the } \\
\text { PABA aqueous } \\
\text { solution }\end{array}$ & 78 & 1.48 & 0.72 & 156 & 19.6 & 0.78 \\
\hline $\begin{array}{l}\text { Pre-sowing seed } \\
\text { treatment by } \\
\text { "Nikfan" }\end{array}$ & 82 & 1.52 & 0.76 & 162 & 19.8 & 0.78 \\
\hline $\begin{array}{l}\text { Pre-sowing seed } \\
\text { treatment by the } \\
\text { PABA + } \\
\text { "Nikfan" mixture }\end{array}$ & 126 & 1.62 & 0.78 & 172 & 20.1 & 0.82 \\
\hline $\begin{array}{l}\text { Pre-sowing seed } \\
\text { treatment + foliar } \\
\text { fertilizing 10-15 } \\
\text { days after } \\
\text { germination }\end{array}$ & 158 & 1.54 & 0.82 & 188 & 20.8 & 0.82 \\
\hline
\end{tabular}

\section{Conclusion}

The use of the biological product "Nikfan" in $0.1 \%$ aqueous concentration, previously mixed with $0.05 \%$ PABA composition for seed treatment, at an exposure time of 2-3 hours, provides a significant increase in the number of nodule nitrogen-fixing bacteria, thereby increasing the amount of biological nitrogen in the soil, and the protein content in the legumes' herbage, and the regrowth rate after mowing. Additional feeding 10-15 days after germination helps to increase the nitrogen fixation of clover and alfalfa, thereby increasing the productivity and quality of plants of important legumes that are needed in the crop rotation system.

\section{References}

1. I. V. Parakhin, Ekologicheskaya ustojchivost' $i$ effektivnost' rastenievodstva (teoreticheskie osnovy $i$ prakticheskij opyt [Ecological sustainability and crop production efficiency (theoretical foundations and practical experience)] (Kolos, Moscow, 2002)

2. V. S. Brzheumykhov, B. Kh. Zherukov, I. V. Kobozev et al., Puti povysheniya simbioticheskoj aktivnosti $i$ produktivnosti lyucerny v usloviyah Severnogo Kavkaza [Ways to increase the symbiotic activity and alfalfa productivity in the North Caucasus] (Publishing house of KBSAU, Nalchik, 2005) 
3. T. N. Dronova, Klever lugovoj na oroshaemyh zemlyah Nizhnego Povolzh'ya [Red clover on irrigated lands of the Lower Volga] (All-Russian Scientific Research Institute for Irrigated Agriculture, Volgograd, 2004)

4. A. M. Hirsch, M. R. Lum, J. A. Downie, Plant Physiol. 127, 1484 (2001). DOI: 10.1104/pp.010866

5. I. A. Tikhonovich, V. A. Agility, Genetika simbioticheskoj azotfiksacii s osnovami selekcii [Genetics of symbiotic nitrogen fixation with the basics of selection] (Nauka, St. Petersburg, 1998)

6. S. A. Bekuzarova, A. D. Bekmurzov I. A. Datieva, G. V. Lushchenko and M. G. Salbieva, IOP Conf. Ser.: Earth Environ. Sci. 421, 062043 (2020). DOI: 10.1088/17551315/421/6/062043

7. B. D. Pinno, S. D. Wilson, Plant Ecology 214, 821 (2013). DOI: 10.1007/s11258-0130210-1

8. S. Isobe, I. Klimenko, S. Ivashuta M. Gau, N. N. Kozlov, Theoretical and Applied Genetics 108, 105 (2003). DOI: 10.1007/s00122-003-1412-z

9. L. V. Drobysheva, G. P. Zyatchina, Ekologicheskaya selekciya i semenovodstvo klevera lugovogo [Ecological selection and seed production of meadow clover], 202 (Elf IPR, Moscow, 2012)

10. S. A. Bekuzarova, N. A. Bome, L. I.Weisfeld, Biology and Communication in the Information Age, 319 (Dalhousie University, Canada, 2013)

11. W. K. Berg, S. M. Cunningham, S. M. Brouder, B. C. Joern, K. K. Johson, J. B. Santini, J. J. Volenec, Crop Science 47, 24 (2007) DOI: 10.2135/cropsci2006.09.0576

12. T. T. Glab, Grass and Forage Science 63, 400 (2008)

13. A. T. Farniev, A. Kh. Kozyrev, A. A. Sabanova, Kh. P. Kokoev, D. K. Khanaeva, L. M. Bazaeva, P. V. Alborova, Indo American Journal of Pharmaceutical Sciences 6, 8956 (2019) 